ISSN $1112-9867$

http://www.jfas.info

\title{
THE CHANGE OF SOIL CHEMICAL PROPERTIES IN DIFFERENCE DEPTH BY IMPACT OF MUNICIPAL WASTEWATER
}

\author{
M. Irandoust*, A. S. Tabriz, K. S. Tabriz and M. R. Forghani
}

Department of Water Engineering, Kerman branch, Islamic Azad University, Kerman, Iran

Published online: 05 June 2016

\begin{abstract}
The most important concern of the authorities in reuse of wastewater through artificial recharge of aquifers, drinking water and water used in agricultural exchange or direct use treated wastewater for health expenditures in different regions of the world, experience has resulted in effluent into account as a reliable source of water to supply the cities considered any parts of the world to supply water to cities and centers of population. In this direction the use of methods based on low quality irrigation water such as wastewater is a practical and convenient solution. The waste can be a rich source of minerals and organicbe considered in order to thefertile soil. In order to assess the effects of wastewater, sewage refined Shiraz on soil chemical properties were analyzed in depth measurement.All samples from the middle of each plot at depths of 0-30 $\mathrm{cm}$ was V30-60And also tested in a randomized complete block design with 3 replications. The results showed a decrease in acidity, salinity, phosphorus, nitrogen and heavy metals concentration in soil irrigated with waste water in the soil is irrigated with well water.
\end{abstract}

Keywords: wastewater; soil chemical properties; the depth measurement; Shiraz.

Author Correspondence, e-mail: Irandostmo@gmail.com

doi: http://dx.doi.org/10.4314/jfas.8vi2s.41 


\section{INTRODUCTION}

Increasingly growing world population. The population growth rate is estimated to average about $7.1 \%$ (merit and Zamyady, 1384).According to estimates, every year 100 million people, or in other words per second more than three people added to the world population.According to the forecasts, in 2025 the world's population of 5.8 billion will go beyond border. Meet the needs of a growing population; the food can be considered a major problem for many nations [1]. In developing countries, the increasing need for fresh water in agricultural production is not limited. But needs per person and also supply the needed water resources industry needs and priorities of the urban communities in these areas.

Existence large population centers and industrial centers in the vicinity of freshwater resources according to the prioritization of municipal and industrial water supply, the share of agriculture in reduced access to these resources [14].These factors have led to the idea of planning to provide new sources of water. Economic resources and in agricultural development and food security needs effectively circulate [23].

If good quality water is scarce, water is considered low quality [43] .The effluent from the wastewater treatment feasibility portion of these resources includeBecause municipal population growth on the one hand and higher levels of public health on the other hand, increased water consumption and high water consumption will have to increase the amount of waste [43] .On the other hand the release of raw sewage in nature and polluting the environment can affect the quality of surface and groundwater flows [23]. While preserving the environment makes utilization of sewage water treatment, recovery and recycling of water is consumed.As a result, use of treated wastewater in agriculture reduces the use of the waters, which in addition to other uses, such as agriculture-could be drinking [13].

The low cost of using treated wastewater for irrigation, groundwater and surface water pollution reduction and reduce the cost of chemical fertilizers in agriculture are other advantages of using treated wastewater [13]. The treated wastewater in irrigation water volume required to include a small amount, but this amount makes use of waters with higher quality can be more important in the application [14]. 
The correct exploitation of municipal waste will reduce surface water pollution problemAnd not only saves water, but also due to the material and is very useful nutrient for plant growth [23] .The availability of this waste near urban centers around these areas provide the potential to increase agricultural production makes [14].Today regarding dry spells in Iran, the growing population, urbanization and industrialization, use of treated wastewater as a source of sustainable agriculture is [15].

Since the wastewater cycle can be used to increase the pollution of groundwater aquifers. Therefore, in recent years in and out of the water purification project gathered outside urban areas is running.t seems that if chemical and biological wastewater pollution problems in food production and soil health not bring, can be used for crop production [13].

With an average annual rainfall of 243 Fars province with more than 15 thousand hectares of cultivated area with limited water resources. One of the city's unconventional water resources, municipal wastewater treatment plant, which since 1386 has started to collect and wastewater treatmentAnd has about 52 thousand subscribers have joined the system. It is anticipated that this plant until 1405 to reach full operation and the effluent reaches the 5/69 million cubic meters per year.

However due to above, it seems that waste water can be treated wastewater, as a reliable source of supply of water, especially in arid and semiarid regions, which are facing a severe shortage of water resources used.If the wastewater is used for irrigation of agricultural lands,Can be taken to save water and fertilizer and also reduce the cost of water supply big step up,Therefore this study was to evaluate the quality of effluent from wastewater treatment plants and Shiraz effluent quality parameters and standards, as well as to determine the rate of change of the elements and parameters to control soil is tested at different depths.

\section{METHODS}

In order to evaluate the effect of treated wastewater the city on the chemical properties of the soil, ground-based experiment with dimensions $8 \times 6 \mathrm{~m}$, in a randomized complete block design with three replications and in non-crop plant, carried out in 1392.Land the city water treatment plant was 200 meters. In this study, after leveling the ground, the plot of which was a 
$2 \times 2$ meters.According to the that there are three replicates of each treatment, total plot was tested 9 Crete

In this study, irrigation water quality experimental plots were two projects were considered as the main cause. Measuring the depth of soil chemical parameters that apply to 30-0 and 60-30 $\mathrm{cm}$ of the soil surface, this research were the subplots.It must be noted that the quality of water entering the experimental plots are as follows:

- Treatment A: Well water (Well water quality is explained below)

- treatment B: municipal wastewater

The study to determine the long-term effects of wastewater on soil chemical properties evaluated, the number of different treatments on the ground 15 times, and an interval of 7 days compared to each other.Water and wastewater, as well as input from each treatment were similar to experimental plots.

Before applying the irrigation to measure physical and chemical parameters of ground, from the depths of 0-30 and 30-60 cm soil samples were taken from the middle of each plotAnd soil and water samples for lab analysis fee of Agriculture and Natural Resources Research Institute in Shiraz was sent.The results of chemical analysis of soil texture and soil are important elements in Tables 1 and 2 are provided.

Table 1. Analysis of soil physical characteristics of the area under study

\begin{tabular}{llllllll}
\hline $\begin{array}{l}\text { Real gravity(gr/ } \\
\mathrm{cm} 3)\end{array}$ & $\begin{array}{l}\text { Apparent specific } \\
\text { weights }(\mathrm{gr} / \mathrm{cm} 3)\end{array}$ & Porosity $(\%)$ & $\begin{array}{l}\text { Soil } \\
\text { texture }\end{array}$ & $\begin{array}{l}\text { Sand } \\
(\%)\end{array}$ & $\begin{array}{l}\text { Silt } \\
(\%)\end{array}$ & $\begin{array}{l}\text { Clay } \\
(\%)\end{array}$ & $\begin{array}{l}\text { Soil } \\
\text { depth } \\
(\mathrm{cm})\end{array}$ \\
\hline 2.67 & 1.42 & 46.8 & $\begin{array}{l}\text { Sandy } \\
\text { loam }\end{array}$ & 57.5 & 28.2 & 14.3 & $0-30$ \\
2.71 & 1.37 & 49.4 & $\begin{array}{l}\text { Sandy } \\
\text { loam }\end{array}$ & 51.3 & 31.9 & 16.8 & $30-60$ \\
\hline
\end{tabular}


Table 2. Chemical analysis of the soil characteristics of the area under study

\begin{tabular}{|c|c|c|c|}
\hline Value & Depth & Unit & Parameter \\
\hline 1.47 & $0-30$ & \multirow{2}{*}{ DS.m } & The electrical \\
\hline 1.01 & $30-60$ & & conductivity \\
\hline 7.1 & $0-30$ & \multirow{2}{*}{ No Unit } & \multirow{2}{*}{ Acidity } \\
\hline 7.4 & $30-60$ & & \\
\hline 1.45 & $0-30$ & \multirow{2}{*}{$\begin{array}{l}\text { Milliequivalents } \\
\text { per liter }\end{array}$} & \multirow{2}{*}{$\begin{array}{l}\text { Sodium absorption } \\
\text { ratio }\end{array}$} \\
\hline 1.37 & $30-60$ & & \\
\hline 3.14 & $0-30$ & \multirow{2}{*}{$\begin{array}{l}\text { Milliequivalents } \\
\text { per liter }\end{array}$} & \multirow{2}{*}{ Sodium } \\
\hline 2.71 & $30-60$ & & \\
\hline 5.85 & $0-30$ & \multirow{2}{*}{$\begin{array}{l}\text { Milliequivalents } \\
\text { per liter }\end{array}$} & \multirow{2}{*}{ Calcium } \\
\hline 4.74 & $30-60$ & & \\
\hline 3.51 & $0-30$ & \multirow{2}{*}{$\begin{array}{l}\text { Milliequivalents } \\
\text { per liter }\end{array}$} & \multirow{2}{*}{ Magnesium } \\
\hline 3.22 & $30-60$ & & \\
\hline 0.0168 & $0-30$ & \multirow{2}{*}{$\begin{array}{l}\text { Milliequivalents } \\
\text { per liter }\end{array}$} & \multirow{2}{*}{ Phosphorus } \\
\hline 0.0121 & $30-60$ & & \\
\hline 0.65 & $0-30$ & \multirow{2}{*}{$\begin{array}{l}\text { Milligrams per } \\
\text { liter }\end{array}$} & \multirow{2}{*}{ Carbonate } \\
\hline 1.02 & $30-60$ & & \\
\hline 0.32 & $0-30$ & \multirow{2}{*}{$\%$} & \multirow{2}{*}{ Organic carbon } \\
\hline 0.18 & $30-60$ & & \\
\hline 0.046 & $0-30$ & \multirow{2}{*}{$\%$} & \multirow{2}{*}{ Total nitrogen } \\
\hline 0.021 & $30-60$ & & \\
\hline 0.0001 & $0-30$ & \multirow{2}{*}{$\begin{array}{l}\text { Milliequivalents } \\
\text { per liter }\end{array}$} & \multirow{2}{*}{ Iron } \\
\hline 0.0001 & $30-60$ & & \\
\hline 0.0003 & $0-30$ & \multirow{2}{*}{$\begin{array}{l}\text { Milliequivalents } \\
\text { per liter }\end{array}$} & \multirow{2}{*}{ Zinc } \\
\hline 0.0003 & $30-60$ & & \\
\hline
\end{tabular}

Also before the test to measure chemical parameters of Well water and wastewater, soil and water samples from them for analysis to the laboratory of the Institute of Agriculture and Natural Resources Research Shiraz was sent.The results of chemical analysis of the important elements of Well water and wastewater (along with Iran's Environmental Protection Organization) is presented in Table 3.According to this table, it can be said that effluent from 
municipal wastewater treatment Shiraz in all parameters compared to the standard provided by the Environmental Protection Organization of Iran (used in agriculture) are at the limit.

Table 3. Analyze the chemical properties of Well water and wastewater use and contaminating the standard border1

\begin{tabular}{|c|c|c|c|c|}
\hline $\begin{array}{l}\text { The border pollution } \\
\text { standards in agriculture }\end{array}$ & $\begin{array}{l}\text { Wastewater } \\
\text { tested }\end{array}$ & $\begin{array}{l}\text { Well } \\
\text { water }\end{array}$ & Unit & $\begin{array}{l}\text { The measured } \\
\text { parameters }\end{array}$ \\
\hline $6-8.5$ & 6.4 & 6.7 & No Unit & Acidity \\
\hline- & 1.63 & 0.85 & DS.m & $\begin{array}{l}\text { The electrical } \\
\text { conductivity }\end{array}$ \\
\hline- & 29.3 & 3.6 & $\begin{array}{l}\text { Milliequivalents per } \\
\text { liter }\end{array}$ & Sodium \\
\hline- & 11.2 & 2.6 & $\begin{array}{l}\text { Milliequivalents per } \\
\text { liter }\end{array}$ & Calcium \\
\hline 14.1 & 13.7 & 2.1 & $\begin{array}{l}\text { Milliequivalents per } \\
\text { liter }\end{array}$ & Magnesium \\
\hline- & 2.03 & 0.85 & $\begin{array}{l}\text { Milliequivalents per } \\
\text { liter }\end{array}$ & Potassium \\
\hline- & 8.4 & 2.4 & $\begin{array}{l}\text { Milliequivalents per } \\
\text { liter }\end{array}$ & $\begin{array}{l}\text { Sodium } \\
\text { absorption ratio }\end{array}$ \\
\hline- & 10.6 & - & $\begin{array}{l}\text { Milliequivalents per } \\
\text { liter }\end{array}$ & Phosphorus \\
\hline- & 0.154 & - & $\%$ & nitrogen \\
\hline- & 0.85 & - & $\%$ & $\begin{array}{l}\text { Total organic } \\
\text { carbon }\end{array}$ \\
\hline- & 2.21 & - & Milligrams per liter & Carbonate \\
\hline 3 & 0.29 & - & $\begin{array}{l}\text { Milliequivalents per } \\
\text { liter }\end{array}$ & Iron \\
\hline 2 & 0.002 & - & $\begin{array}{l}\text { Milliequivalents per } \\
\text { liter }\end{array}$ & Zinc \\
\hline
\end{tabular}

1: Iran's Environmental Protection Organization standards (for agriculture) 
The study measured physical and chemical properties of the soil with the help of Soil and Water Laboratory Research Center for Agriculture and Natural Resources Shiraz.Therefore goes on to describe the measured parameters and methods of measuring it is explained briefly:

Soil acidity: after preparing soil samples considered, the acidity of $\mathrm{pH}$ meter by 620 -ohm meter was measured.

The electrical conductivity of soil: To calculate the conductivity of the device model $646 \mathrm{ohm}$ meter conductivity meter was used.

Sodium and potassium: The two ions of ammonium acetate normal and to help Corning 410 photometer film device were measured.

Calcium and Magnesium: These two ions were measured by titration with a solution Orsini Phosphorus: this ion was measured by Olsen. The five g dry soil, $100 \mathrm{ml}$ half-normal sodium bicarbonate was added to $\mathrm{pH}$ 5.8. After diluting the extract, diluted extract phosphorus by colorimetric spectrophotometer model with the help of Bush and the lamp model 20 was measured

Organic carbon: These ions was measured by using black linen

Nitrogen: Soil nitrogen was measured to the Kjeldahl method. The method of soil nitrogen by sulfuric acid in the presence of a catalyst (copper sulphate, potassium and selenium) oxide and ammonium sulfate becameAnd the nitrogen to ammonia distillation step and then using boric acid and by sulfuric acid to form ammonium become normal 005/0 was the headline.

Zinc and iron: The two ions that the heavy elements are analyzed by atomic absorption spectrophotometer equipped with a graphite furnace were measured according to the method described by APHA.

Finally, the study data were analyzed using SAS softwareAlso the charts from Microsoft Excel was used. It must be noted that the comparison of means were performed by Duncan test.

\section{DISCUSSION AND CONCLUSIONS}

\subsection{Analysis of variance treatments}

Analysis of variance related to water quality as a result of two main factors, the measured depth (as a subsidiary) and their interactions on the chemical properties of the soil reflects the factThe effect of quality on all traits was meaningfula at the level of one percent.But the depth of the 
traits measured in Sodium absorption ratio, sodium, calcium, magnesium, zinc and iron instead of their other traits have a significant effectHowever, the interaction between agents and sub-component attributes a significant effect on phosphorus and carbonate, the other characters is meaningless.

Table 4. Analysis of variance

\begin{tabular}{|c|c|c|c|c|c|c|c|}
\hline Magnesium & Calcium & Sodium & $\begin{array}{l}\text { Sodium } \\
\text { absorption } \\
\text { ratio }\end{array}$ & Acidity & $\begin{array}{l}\text { The } \\
\text { electrical } \\
\text { conductivity }\end{array}$ & $\begin{array}{l}\text { Degrees } \\
\text { of } \\
\text { freedom }\end{array}$ & $\begin{array}{l}\text { Source } \\
\text { Changes }\end{array}$ \\
\hline $0 / 0041$ & 0/0098 & 0.0012 & 0.0687 & 0.084 & 0.0022 & 2 & $\begin{array}{l}\text { Repeat } \\
\text { Rep }\end{array}$ \\
\hline $0 / 91^{* *}$ & $0 / 45^{* *}$ & $* * 0.76$ & $* * 0.81$ & $* * 0.07$ & $* * 0.457$ & 1 & $\begin{array}{l}\text { Water } \\
\text { Quality A }\end{array}$ \\
\hline $0 / 59$ & $0 / 39$ & 0.22 & 0.93 & 0.51 & 0.846 & 2 & Error(E1) \\
\hline $\mathrm{ns} 0 / 32$ & ns $0 / 73$ & $\mathrm{~ns} 0.58$ & $\mathrm{~ns} 0.24$ & $* * 0.079$ & $* * 0.0247$ & 1 & $\begin{array}{l}\text { Measured } \\
\text { depth B }\end{array}$ \\
\hline ns0/01 & ns0/06 & ns0.03 & $\mathrm{ns} 0.18$ & $0.0174 \mathrm{~ns}$ & $0.0531 \mathrm{~ns}$ & 1 & $\begin{array}{l}\text { reaction } \\
\mathrm{AB}\end{array}$ \\
\hline 0/068 & 0/011 & 0.032 & 0.14 & 0.115 & 0.72 & 3 & Error(E2) \\
\hline
\end{tabular}

**:meaningfula\& ns: meaningless

Continued Table 4

\begin{tabular}{lccccccc}
\hline Zinc & Iron & $\begin{array}{l}\text { Total } \\
\text { nitrogen }\end{array}$ & $\begin{array}{l}\text { Organic } \\
\text { carbon }\end{array}$ & Carbonate & Phosphorus & $\begin{array}{l}\text { Degrees } \\
\text { of } \\
\text { freedom }\end{array}$ & $\begin{array}{l}\text { Source } \\
\text { Changes }\end{array}$ \\
\hline $0 / 0328$ & $0 / 0807$ & $0 / 0412$ & $0 / 0589$ & $0 / 0073$ & $0 / 073$ & 2 & $\begin{array}{l}\text { Repeat } \\
\text { Rep }\end{array}$ \\
$0 / 024^{* *}$ & $0 / 057^{* *}$ & $0 / 001^{* *}$ & $0 / 321^{* *}$ & $0 / 0045^{* *}$ & $0 / 56^{* *}$ & 1 & $\begin{array}{l}\text { Water } \\
\text { Quality A }\end{array}$ \\
$0 / 072$ & $0 / 094$ & $0 / 014$ & $0 / 808$ & $0 / 325$ & $0 / 54$ & 2 & Error(E1) \\
ns0/068 & ns0/021 & $0 / 0047^{* *}$ & $0 / 29^{* *}$ & $0 / 092^{* *}$ & $0 / 71^{* *}$ & 1 & Measured
\end{tabular}


depth B

$\begin{array}{lccccccc} & & & & & & \text { depth B } \\ \text { ns0/02 } & \text { ns0/081 } & \text { ns0/0054 } & \text { ns0/048 } & 0 / 018^{* *} & 0 / 04 * * & 1 & \text { reaction } \\ 0 / 079 & 0 / 061 & 0 / 0098 & 0 / 621 & 0 / 802 & 0 / 056 & 3 & \text { Error(E2) }\end{array}$

**:meaningfula\& ns: meaningless

\subsection{Assessment indicators of soil electrical conductivity}

The results of the data analysis traits (Table 4) show that the effect of water quality on meaningful attribute is the electrical conductivity.According to the study which is almost 2 times salinity water salinity Well water has been used,Therefore increase in soil salinity wastewater Bh $\neg$ Dnbal application is not expected.In this regard, results of analysis, the average electrical conductivity of the soil after irrigation with well water and treated wastewater that was performed by Duncan test at the level of one percent,Shows (Figure 1), which applies water to the soil to increase soil salinity of the irrigation Well water was of 5.42 percent.

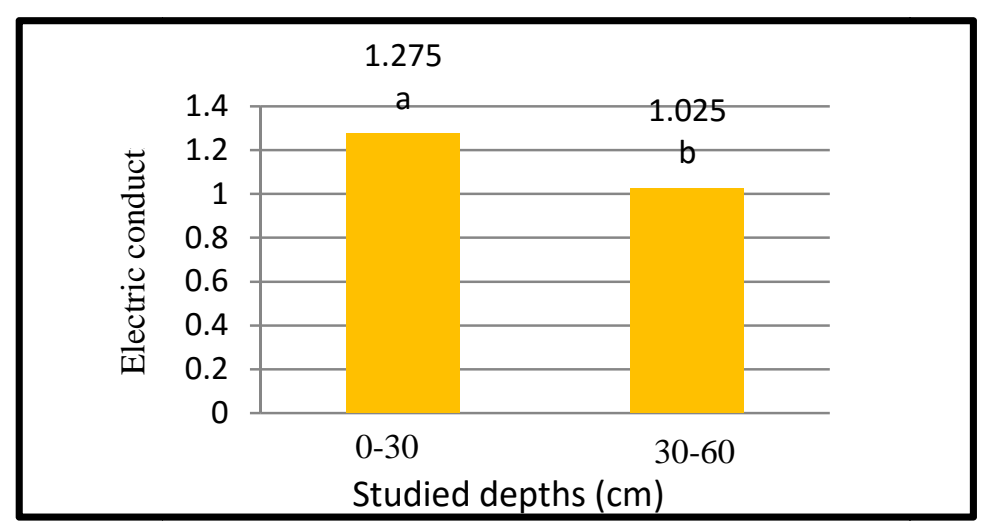

Fig.2. Compares the average effect of depth measurement of the electrical conductivity of the soil

\subsection{Assessment indicators of soil acidity}

The results of the data analysis traits (Table 4) show that the effect of water quality on meaningful attribute is the acidity. Compare the average acidity of the soil quality indicators show that the acidity of the soil by the use of waste water for irrigation to soil acidity, decreased (Figure 3).As specified in this way reduce the acidity of the soil in irrigation with treated wastewater to irrigate with well water is about $6 \%$. 


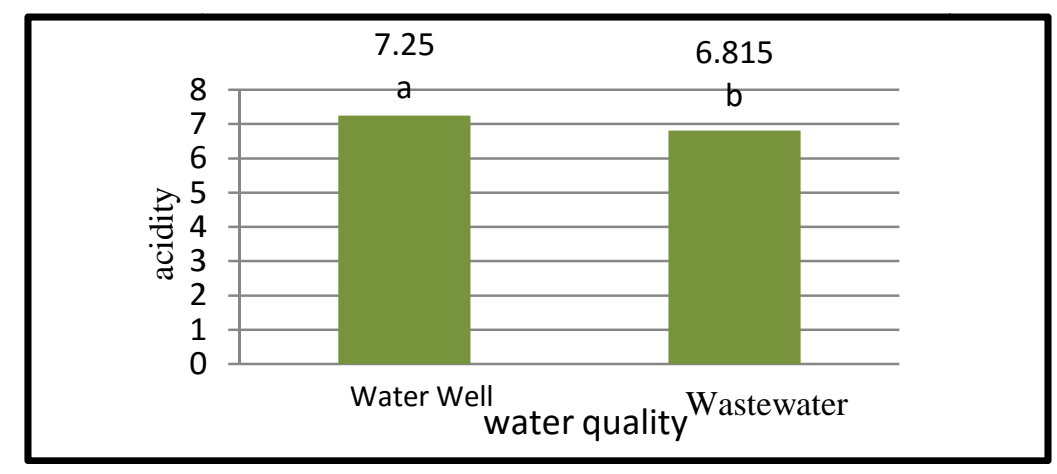

Fig.3. Compares the average effect of water quality on soil acidity

The results of the data analysis traits (Table 4) show that the effect of depth is the measurement of the characteristic electrical conductivity meaningful. Therefore comparison of the mean acidity of the soil in the studied depths (Figure 4), which with increasing depth, the soil acidity increasesThe increase soil acidity level of about 9.3 percent.Appears to reduce the acidity of the soil at the soil surface to the depths of the reasonThat Since the the soil is favorable conditions for the entry of air into the soil, the rate of decomposition of organic matter including nitrification process, which reduces soil acidity plays [25].

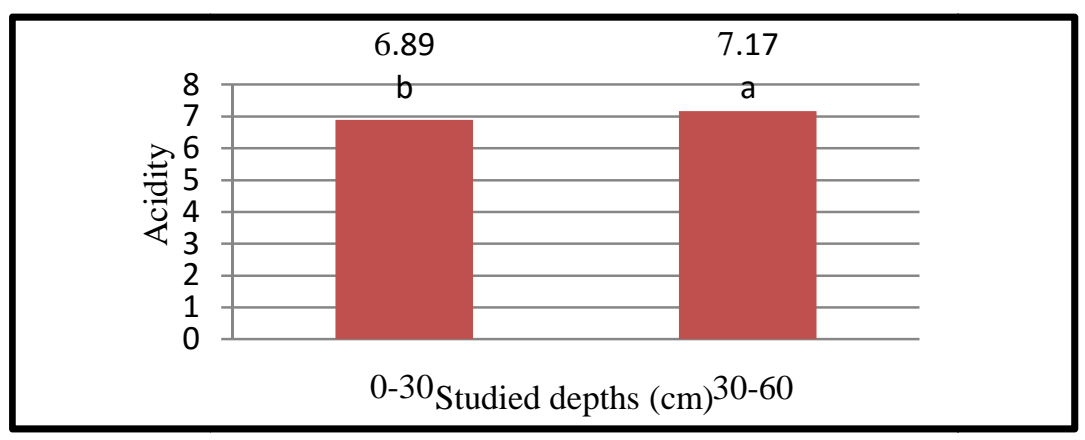

Fig.4. Compares the average measured depth effect on soil acidity

\subsection{The sodium adsorption ratio analysis to evaluate the soil and its components}

The results of the data analysis traits (Table 4) shows that as The sodium adsorption ratio, sodium, calcium and magnesium are the qualities that only the effect of water quality on them is meaningful.Therefore, these attributes mean comparison analysis was performed by Duncan test at the level of one percent, show (Table 5)Irrigation with wastewater in order to increase 4/23, 9/64, 3/78 and 8/78 percent sodium absorption, sodium, calcium and magnesium led to 
well water.Acts wastewater rich in sodium, the natural balance of the soil solution on the My $\neg$ Znd cations leading to the replacement of sodium with other cations, particularly calcium and magnesium in the soil, which thereby increased levels of exchangeable sodium adsorption ratio in the [38].

In this study, since the amount of The sodium adsorption ratio raw soil is acceptable, The results indicate that irrigation with treated wastewater The sodium adsorption ratio in the city, compared to the initial amount of sodium absorption ratio, increasedBut this increase is less than the threshold set by the World Food OrganizationAnd the destruction of soil structure and infiltration problem to beBut if they continue with such $r$.

Table 5. The effect of water quality on some elements

\begin{tabular}{|c|c|c|c|c|}
\hline \multirow[b]{2}{*}{ Water Quality } & \multicolumn{4}{|c|}{ Elements examined (Milliequivalents per liter) } \\
\hline & Sodium & Calcium & Magnesium & $\begin{array}{l}\text { The sodium } \\
\text { adsorption } \\
\text { ratio }\end{array}$ \\
\hline Water Well & b5/34 & $\mathrm{b} 2 / 3$ & b2/1 & b3/6 \\
\hline $\begin{array}{l}\text { The treated } \\
\text { wastewater }\end{array}$ & a15/25 & $\mathrm{a} 10 / 6$ & a9/9 & $\mathrm{a} 4 / 7$ \\
\hline
\end{tabular}

\subsection{Assessment of soil carbon decomposition and phosphorus}

Phosphorus as a nutritional factor contributing to the phenomenon Eutrophication is the transfer of surface water and underground water resources entail reduced quality[8]. The results of the data analysis traits (Table 4) show thatPhosphorus soil carbon characteristics and attributes that in addition to the meaningful effect on the primary and secondary factors, interaction between major and minor factors on these traits is significant.Therefore, these attributes mean comparison analysis was performed by Duncan test at the level of one per cent, is shown (Fig. 5 and 6).

Analyze soil characteristics before testing (Table 2) show that the studied soil at depths of 0-30 and 30- $60 \mathrm{~cm} 0.0168$ and 0.0121 respectively Mylyakyvalant containing phosphorus.As well 
as the chemical properties of water and wastewater analysis used (Table 3) show that the well water used but no phosphorus wastewater containing phosphorus Valant $6.10 \mathrm{mEq}$.Thus, according to Figure 5, it can be said that the irrigation with well water due to lack of phosphorus in water depths of 0-30 and 30 . The $\mathrm{P} 60 \mathrm{~cm}$ respectively in 8.3 and $15.7 \%$ of the phosphorus in the soil before testing decreased.But irrigation with treated wastewater phosphorus in the depths of 0-30 and 30- $60 \mathrm{~cm}$ respectively in the 94.7 and 91.3 percent phosphorus increased soil before testing.Boyle et al (1981) study on land that has been refined over the years by irrigation with sewage water for irrigation-have of the land that had been indicated that a significant amount of phosphorus in the water with wastewater increases.

Another issue to be listed on this form, it can be noted that the amount of phosphorus decreases with increasing depthIn this regard, numerous scholar noted that due to the low solubility of phosphorus in the soil, the accumulation of phosphorus in the soil surface layer is substantially ([40]; [8] ; [16]).While phosphorus measured at a depth of 0-30 $\mathrm{cm}$ soil and irrigated with treated wastewater is statistically the best positionMeasured at a depth of 30-60 cm and phosphorus treatment and irrigation with treated wastewater by $56.25 \%$ relative difference in treatment in the best position has been analyzed, statistically at position (b) is located.It should be noted that despite the differences between the two depth measurement 33.8 percent0-30 and $30-60 \mathrm{~cm}$ of water for irrigation, these two treatments statistically in a group (c) are located.

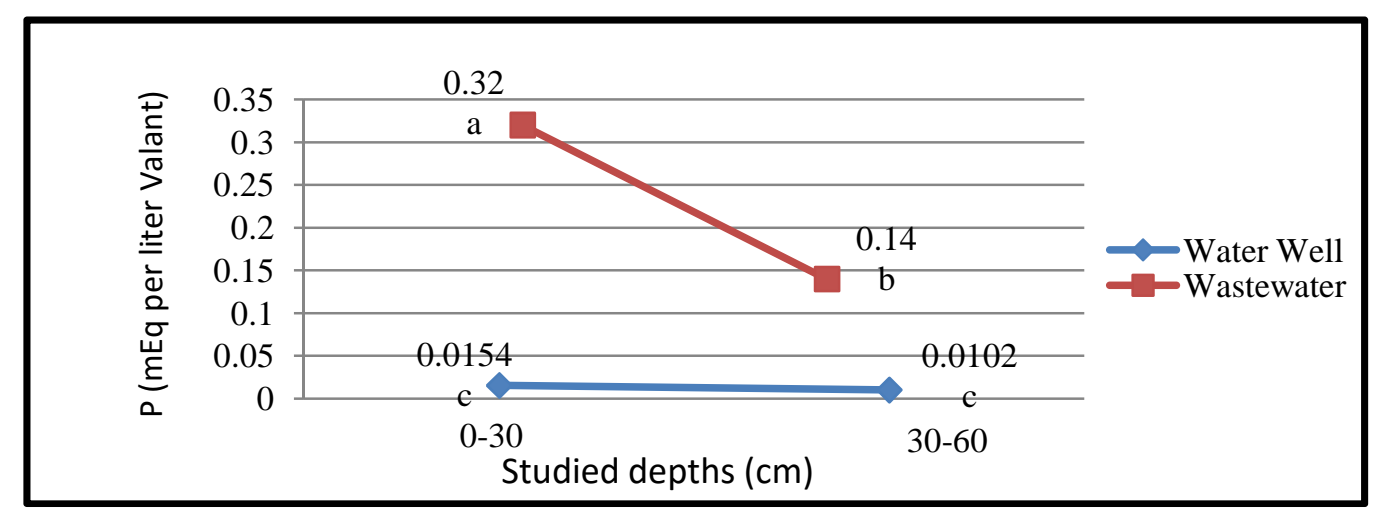

Fig.5. Mean comparisons of the primary and secondary factors on soil phosphorus

Analyze soil characteristics before testing (Table 2) show that the studied soil at depths of 0-30 and $30-60 \mathrm{~cm} 0.65$ and 1.02 milligrams per liter respectively containing carbonate.As well as the chemical properties of water and wastewater analysis used (Table 3) show that the well 
water used is free of carbonBut wastewater contains 21.2 milligrams per liter carbonate.Thus, according to Figure 4-6, it can be said that due to lack of irrigation water for the amount of carbon in the carbonate in water depths of $0-30$ and $30-60 \mathrm{~cm}$ respectively in 21.05 and $12.7 \%$ compared to pre-test the soil carbon declined.But irrigation with treated wastewater carbon content in the depths of 0-30 and 30- $60 \mathrm{~cm}$ respectively in the 38.7 and 44.6 percent increase in soil carbon before testing.

Another issue to be listed on this form, it can be noted that the carbon content increases with increasing depthIn this study, measured at a depth of 30-60 cm soil carbonate and irrigated with treated wastewater is statistically the best positionMeasured at a depth of 0-30 $\mathrm{cm}$ and carbonate treated soil and irrigated with wastewater treatment difference 42.4 percent in the best position has been analyzed, statistically at position (b) is located.The two irrigation wells with depths of 0-30 and 30-60 cm measured on 72.3 and 51.6, respectively, with the difference that in the best position\% compared to treatment was analyzed, statistically respectively, in place of (d) and (c) are located.

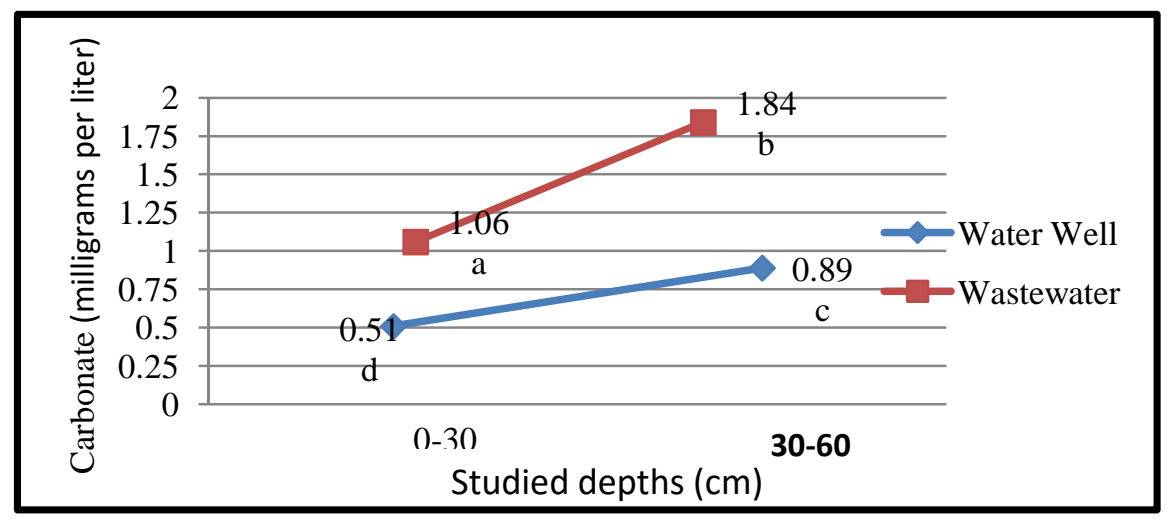

Fig.6. compares the average interaction of agents and sub-soil carbon

\subsection{Evaluation of soil organic carbon sequestration}

The results of the data analysis traits (Table 1) shows that the effect of water quality on the attributes of organic carbon is significant.The comparison of average soil organic carbon analysis of well water and treated wastewater by Duncan test was a percentage, shows (Fig. 7), which apply water to the soil increase the carbon content 67.8 organic soil to be well water. 


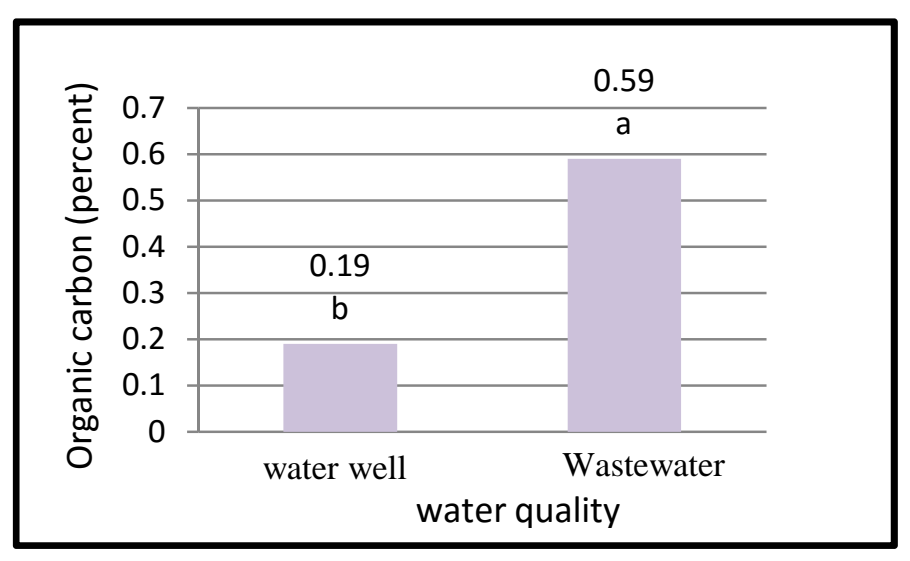

Fig.7. Compares the average effect of water quality on soil organic carbon

The results of the data analysis traits (Table 1) show that the effect of depth measurement of the quality of soil organic carbon is significant. The comparison of the mean soil organic carbon in the depths studied (Fig. 8), which with increasing depth, soil organic carbon content is reduced.

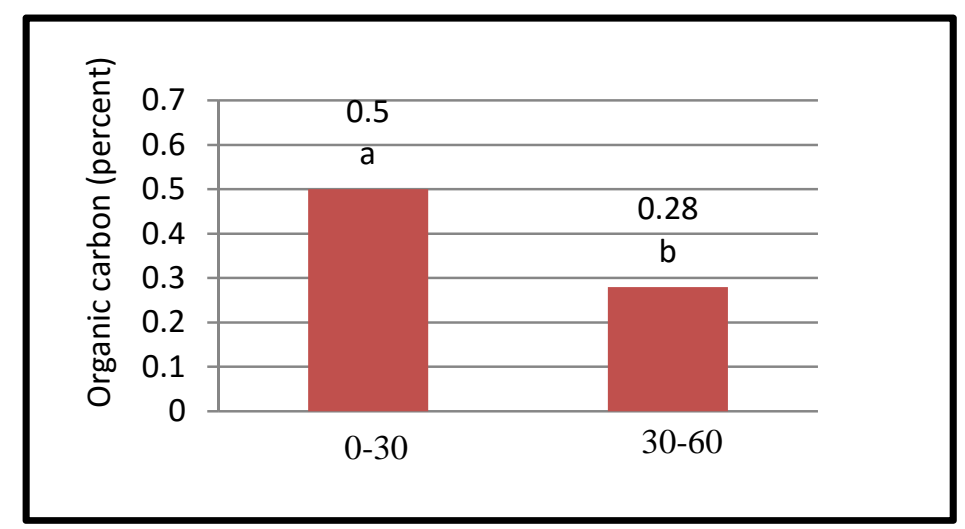

Fig.8. Compares the average measured depth effect on soil organic carbon

\subsection{Assessment indicators of soil nitrogen}

Analyze soil characteristics before testing (Table 2) show that the studied soil at depths of 0-30 and $30-60 \mathrm{~cm}$, respectively, 0.046 and 0.021 percent of nitrogen.Also the chemical properties of water and wastewater analysis used (Table 3) show that the well water used is the non-carbonate but containing $2.154 \%$ of nitrogen wastewater.

The results of the data analysis traits (Table 4) show that the effect of water quality on the attributes of nitrogen is significant.The comparison of average soil nitrogen analysis of well water and treated wastewater shows (Fig. 9), which apply water to the soil to increase soil nitrogen than well water was $68.1 \%$. 


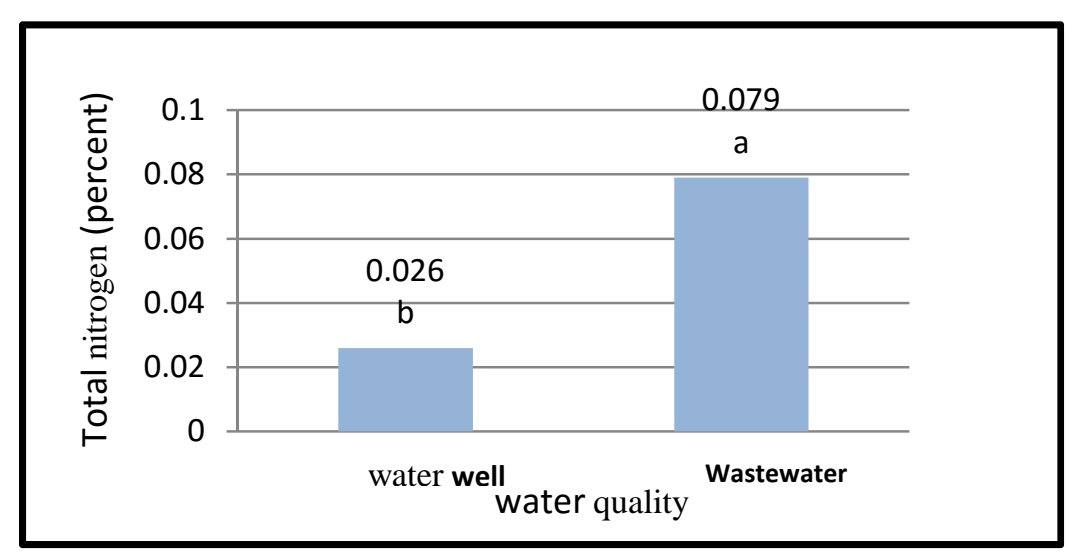

Fig.9. Compares the average effect of water quality on soil nitrogen

The results of the data analysis traits (Table 4) show that the effect of depth measurements as soil nitrogen is significant.So comparison shows the average nitrogen soil studied in depth (Figure 10), which with increasing depth, soil nitrogen content is reduced, so that the nitrogen in the soil at a depth of $0-30 \mathrm{~cm}$ from the 40.9 percent rate increase soil nitrogen at a depth of 30-60 $\mathrm{cm}$. The reason it can be noted that the accumulation of organic matter in surface soil profile Tvjhbhaynkh more, most likely the amount of nitrogen in the soil, due to the decomposition of organic matter and release of ammonium, nitrate, resulting in the phenomenon, increased anion in the soil is Pydashth[37].

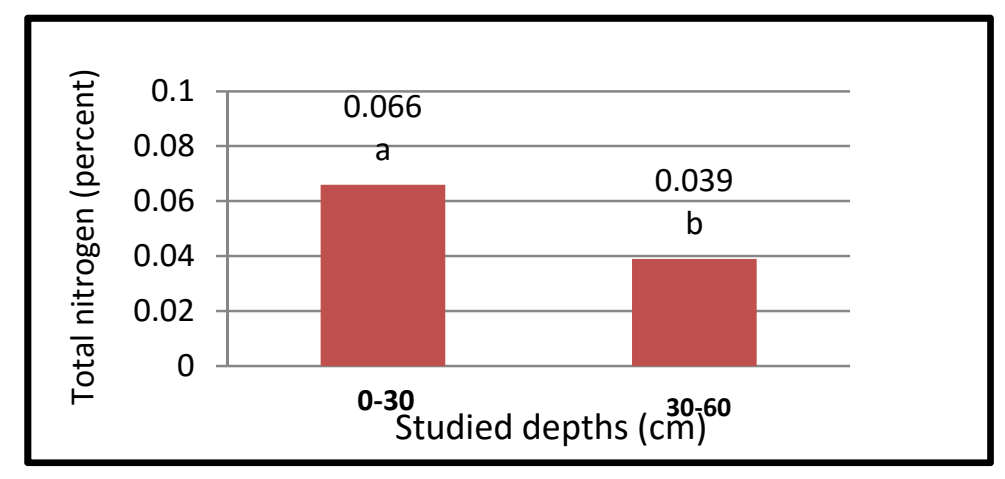

Fig.10. Compares the measured average depth effect on soil nitrogen 


\subsection{Assessment analysis of heavy metals in soil}

The results of the data analysis traits (Table 4) show that the effect of water quality on the attributes of iron and zinc is significant.So results of analysis, the average iron and zinc soil after irrigation water and wastewater shows (Figure 11), which apply water to the soil increased 88.2 and 46.4 percent respectively, iron and zinc soil than water with the well water.

Table 6. Impact of Water Quality on heavy metals

\begin{tabular}{ccc}
\hline \multirow{2}{*}{ Water Quality } & \multicolumn{2}{c}{ Elements examined (mEq per liter) } \\
\cline { 2 - 3 } Water Well & Iron & Zinc \\
\hline The treated wastewater & $\mathrm{b} 0001.0$ & $\mathrm{~b} 003.0$ \\
\hline
\end{tabular}

\section{DISCUSSION AND CONCLUSION}

The study showed With increasing depth of soil acidity increases by 3.9 percent.t seems to reduce the acidity of the soil at the soil surface to the depths of the reason is thatBecause the conditions for the entry of air into the soil at the soil surface is favorable, the rate of decomposition of organic matter including nitrification process to be followed to reduce the acidity of the soil

With increasing depth of soil electrical conductivity was reduced to 19.6 percent. Because of falling electrical conductivity can-be explained in depth in terms of waste applied to soil, accumulation of organic matter in the soil increases and the lack of opportunity for use of decomposition of organic matter, water infiltration into the soil deep down that whereby the conditions for the accumulation of salt in the soil, So increasing soil salinity in the surface layers of soil.

The study showed that irrigation with The treated wastewater increased 42.5 percent soil electrical conductivity of the irrigation water was well.Increase the electrical conductivity of soil in irrigation with wastewater can be linked to high concentrations of cations such as sodium, leading to increased soil electrical conductivity in the wastewater is sentIrrigation with The treated wastewater Also reduces soil acidity than 6 percent of the irrigation water was 
well.Because of falling soil acidity can increase in terms of waste organic materials, formed materials, intermediate acidic gases such as hydrogen sulfide and communication.Irrigation with The treated wastewater increase of 23.4 percent from SAR to irrigation water was wellBecause of the increased sodium absorption ratio can be explained as acts of wastewater rich in sodium, the natural balance of ions in the soil solution disrupts and led to the replacement of sodium with calcium and magnesium cations other especially on the surface of the soil exchangeable which will be followed by SAR.

Irrigation with the treated wastewater increased 67.8 and 68.1 percent, respectively, organic carbon and nitrogen to the soil irrigated with well water was treated.With increasing depth of phosphorus and organic carbon in the amount of 56.25 and 44 percent respectively but with the increasing depth of soil carbon to the $42.4 \%$ increase. With increasing depth of soil nitrogen is reduced to 40.9 percent.. The reason it can be noted that the accumulation of organic matter in surface Considering that soil profile is more likely to be high nitrogen content in the soil, due to the decomposition of organic matter and the release of ammonia, which results in a phenomenon nitrate latest increase anion in the soil.

\section{SUGGESTIONS}

Therefore it is recommended that the effect of irrigation with The treated wastewater city of tests on the quality of agricultural products to beAnd on the impact of wastewater on the quality of surface and groundwater resources studies doneAlso research in the field of efficient use of water from this source be made to health hazards resulting from the use of The treated wastewater to a minimum raise.

Studies on the impact of suspended solids in the treated wastewater and hydraulic behavior of soil permeability can be useful.At the end of the recommended studies on the uptake of sewage on possible deficiencies in the plants be taken to correct it by adding other fertilizers.

\section{REFERENCES}

[1] Arvand-s. And kamyab, moghadas, R. One of the most important strategies to cope with water scarcity efficient use of urban wastewater, Proceedings of the First National Conference discuss strategies to deal with water scarcity and drought, 2010. 
[2] Asgharzadih, A. Sewage sludge and debris hay on some physical and chemical properties of the soil, MA Thesis, Department of Water Engineering University of Kerman Islamic Azd, 2012.

[3] Ansari, H., Noble, even. And judgment, which, in 2009, the principles and practices of public irrigation, publications (SID), p. 316.ISO/DIS 16000-6.2, Indoor Air - Part 6: Determination of Volatile Organic Compounds in Indoor and Chamber Air by Active Sampling on TENAX TA Sorbent, Thermal Desorption and Gas Chromatography using MSD/FID. Geneva, International Organization for Standardization, 2002.

[4] Baiburdi, M. Irrigation management, publication, water, soil, tools, 1994, 1: 21-33.

[5] Tqvayyan, p., Alizadeh. Knowledge of the impact of wastewater irrigation on soil chemical and physical properties, the journal Irrigation and Drainage, 2007, 42: 2-11.

[6] Tavakoli, M. And Tabatabai, M. Irrigation with the treated wastewater, using wastewater for irrigation and environmental aspects of the Proceedings of the National Committee on Irrigation and Drainage, Tehran, 2008.

[7] Hossein Pur, O., Haghnia, Gh., Alizadeh. To examine the changes the chemical quality of raw sewage and waste water passes through the soil StvnᄀHay Journal of soil and water,2009, 23: 45-56.

[8] Hossein Pur, O., Haghnia, Gh. To examine the changes the chemical quality of raw sewage and waste water passes through the soil StvnᄀHay Journal of soil and water, 2009, 23: 45-56.

[9] Hanif Lu, of. And Moazedi, E. The effects of irrigation with treated wastewater in Ahvaz on soil hydraulic properties, the Journal of Agricultural Engineering Research, 2007, 2: 47-62.

[10] Rohani, Shahraki, F., Mahdavi, the. And Rezaei, M. The effect of irrigation with wastewater on some physical and chemical properties of soil, water and sanitation Journal, 2005, 53: 23-29.

[11] Salemi, C. And Musharraf, L. Byary impact on the quality and yield of Zrtdanh $\neg$ Ay in the Journal of Agricultural Engineering Research, 2006, 26: 84-71. 
[12] Shabanian, H. The effect of wastewater and sewage sludge POLYACRYL plant growth and heavy metal concentrations in some samples of wheat plants and green areas, master's thesis, Faculty of Agriculture, University of Technology, 2004, 117.

[13] Salehi, N. changes the physical and chemical properties of soils irrigated with the treated wastewater urban pistachio, MA Thesis, Department of Water Engineering martyr Bahonar University, 2010.

[14] Abedi, d. C. And Najafi, C. Use of treated wastewater in agriculture, published by the National Committee on Irrigation and Drainage, 2001, No. 47.

[15] Abedi, Koopayee, J., Opiates, M., Mousavi, s. F., Mostafa M., b. And Bagheri, M. The effect of sprinkler irrigation and surface treated wastewater on soil salinity, water and sanitation magazine, 2003, 45: 2-12.

[16] Amer. AS. Study the effects of different ratios of wastewater irrigation on soil physical and chemical characteristics. Master's thesis, Department of Water Engineering University of Kerman Islamic Azd, 2012.

[17] Ali khales, d. And small S, M. The effect of irrigation with the treated wastewater Zinc private cotton plant, Iranian Journal of Soil and Water Research, 2010, 2: 235-229.

[18] Ghanbari, a., S. Abedi, J. And TAIE, Jul. The effect of irrigation with wastewater Zinc yield and quality of wheat and some soil properties in Sistan, Science and Technology of Agriculture and Natural Resources, 2006, 4: 74-59.

[19] Karimzadeh, M., Alizadeh, a., Aria Mohammadi, M. The effects of wastewater irrigation on soil saturated hydraulic conductivity, soil and water Journal, 2012, 26: 1547-1553.

[20] Liaqat, AS. And Zamyady, a. The irrigation methods in agriculture, published by the National Committee on Irrigation and Drainage, 2005, 186.

[21] Maleki, A. The impact of water and treated wastewater and combined sewer Kerman both the physical and chemical properties of soil and drainage, MA Thesis, Department of Water Engineering, Islamic Azad University of Kerman, 2012.

[22] Malakooti, m. and Exquisite, M. Fertilizer consumption in the agricultural lands, Tarbiat Modarres University, 1994. 
[23] Najafi, C., Mousavi, F and Feyzi, M. The effects of urban the treated wastewater on yield and quality of wheat, Journal of Agricultural Sciences and Natural Resources, 2007, (1): $15-25$.

[24] Aiello, R., Cirelli, G.L., Consoli, S. Effects of reclaimed wastewater irrigation on soil and tomato fruits: A case study in Sicily (Italy), Agricultural Water Management, 2007, 93, 65-72.

[25] Blum J, Herpin U, Melfi A J, Montes C R. Soil properties in a sugarcane plantation after the application of treated sewage effluent and phosphogypsum in Brazil. Agricultural Water Management, 2012, 115:203-216.

[26] EPA. Technical support documents for 40 CFR. Part 503. Land application of sewage sludge. Vol.1-PB93-11075."Land application of sewage sludge". Vol.2-PB93-110583. Appendices A-L. Spring Field, VA: National Technical Information Service, 1993.

[27] FAO, Wastewater treatment and use in agriculture. Food and Agriculture Organization of the United Nations, Rome, 1992, P: 47.

[28] Gamito, P., Arsenio, A., Faleiro, M.L., Brito, J.M. and Beltrao, J. The influence of wastewater treatment of irrigation water quality. In: Proceedings of: International Workshop on: Improved crop quality by nutrient management, 29 Sep -01 Oct 1999, Izmir, Turkey, pp. 267-270.

[29] Heidarpour, M., Mostafazadeh-Fard, B., Abedi Koupai, J., Malekian, R. The effects of treated wastewater on soil chemical properties using subsurface and surface irrigation methods, Agricultural Water Management, 2007, 90: 87-94.

[30] Jahantigh, M, Impact of recycled wastewater irrigation on soil chemical properties in an arid region. Pakistanian Journal of Biological Sciences, 2008, 11: 2264-2268.

[31] Kabata-Pendias, A. and H. Pendia, 1992, Trace element in soils and plants.CRC press. Boca Raton Ann Arbor. London, 1992, P: 223.

[32] Kaschl, A., V. Romheld, and Y. Chen. The influence of soluble organic matter from municipal solid waste compost on trace metal leaching in calcareous soils. The Science of the Total Environment, 2002, 291: 45-57. 
[33] Khai N, Tuan P, Vinh C, Oborn I. Effects of using wastewater as nutrient sources on soil chemical properties in peri periurban agricultural systems. Journal of Science, Earth Sciences, 2008, 24: 87-95.

[34] Magesan G N, Williamson J C, Yeates G W, Lloyd-Jones A R. Wastewater C:N ratio effects on soil hydraulic conductivity and potential mechanisms for recovery. Bioresource Technology, 2000, 71:21-27.

[35] Mapanda, F., Mangwayana, E.N., Nyamangara, J., Giller, K.E. The effect of long-term irrigation using wastewater on heavy metal contents of soils under vegetables in Harare, Zimbabwe, Agriculture, Ecosystems \& Environment, 2005, 107, 151-165.

[36] Martens, D. C and Westermann, D. T. Fertilizer application for correcting micronutrient deficiencies. Journal of Micronutrient in Agriculture, SSSA Books, Wisconsin, USA, 1991, 549-592.

[37] McLaren R G, Clucas L M, Taylor M D, Hendry T. Leaching of macronutrients and metals from undisturbed soils treated with metal-spiked sewage sludge, Leaching of macronutrients, Australian Journal of Soil Research, 2003, 41:571-588.

[38] Meli, S., Porto, M., Belligno, A., Bufo, S.A., Mazzatura, A., Scopa, A. Influence of irrigation with lagooned urban wastewater on chemical and microbiological soil parameters in a citrus orchard under Mediterranean condition, Science of The Total Environment, 2002, 285(1-3), 69-77.

[39] Menegaki, A.N., Hanley, N. and Tsagarakis, K.P. The social acceptability and valuation of recycled water in Crete: A study of consumers' attitudes. Eecological Economics, 2007, 62, $7-18$.

[40] Mojiri, A., 2011, Effects of municipal wastewater on physical and chemical properties of saline soil. Journal of Biology, Environ Science, 2011, 14: 71-76.

[41] Najafi P, Nasr S. Comparison effects of wastewater on soil chemical properties in three irrigation methods. Research on Crops; 2009, 10:277-280.

[42] Papadopoulos A, Bird N R A, Whitmore A P, Mooney S J., 2014, Does organic management lead to enhanced soil physical quality. Geoderma, 2014, 213:435-443. 
[43] Pescod, M.B. Wastewater Treatment and Use in Agriculture. FAO United Nations, Rome, Itlay, 1992, Pages: 125.

[44] Rezapour, S., Samadi, A., Khodaverdiloo H. Impact of long-term wastewater irrigation on variability of soil attributes along a landscape, semi-arid region of Iran, Environmental Earth Sciences, 2012, 67, 1713-1723.

[45] Sepaskhah A R, Karizi A. Effects of alternate use of wastewater and fresh water on soil saturated hydraulic conductivity, Journal of agronomy and soil science, 2011 57:149-158.

[46] Singh, G.and M.Bahati., Growth and mineral accumulation in Eucalyptus camaldulensis seedlings irrigated with mixed industrial effluents. Bioresource Technology, 2003, $88: 221-228$.

[47] Song, Y.F., Wilke, B.-M., Song, X.Y., Gong, P., Zhou, Q.X., Yang, G.F. Polycyclic aromatic hydrocarbons (PAHs), polychlorinated biphenyls (PCBs) and heavy metals (HMs) as well as their genotoxicity in soil after long-term wastewater irrigation, Chemosphere, 65", 2006, 1859-1868.

[48] SouDakoure M Y, Mermoud A, Yacouba H, Boivin P., Impacts of irrigation with industrial treated wastewater on soil properties. Geoderma, 2013, 200-201:31-39.

[49] Xu, J., Wu, L., Chang, A.C., Zhang, Y. Impact of long-term reclaimed wastewater irrigation on agricultural soils: A preliminary assessment, Journal of Hazardous Materials, 2010, 183: 780-786

\section{How to cite this article:}

Irandoust M, Tabriz A. S, Tabriz K. S. and Forghani M. R. The change of soil chemical properties in difference depth by impact of municipal wastewater. J. Fundam. Appl. Sci., 2016, $8(2 S), 337-358$. 